\title{
Tetrandrine suppresses adhesion, migration and invasion of human colon cancer SW620 cells via inhibition of nuclear factor- $\kappa B$, matrix metalloproteinase-2 and matrix metalloproteinase-9 signaling pathways
}

\author{
TA-KUO JUAN ${ }^{1}$, KUO-CHING LIU ${ }^{2}$, CHAO-LIN KUO $^{3}$, MEI-DUE YANG ${ }^{4}$, YUNG-LIN CHU ${ }^{5}$, \\ JIUN-LONG YANG ${ }^{2}$, PING-PING WU ${ }^{6}$, YI-PING HUANG ${ }^{7}, \mathrm{KUANG}^{-C H I}$ LAI $^{8-10}$ and JING-GUNG CHUNG ${ }^{1,11}$ \\ Departments of ${ }^{1}$ Biological Science and Technology, ${ }^{2}$ Medical Laboratory Science and Biotechnology and \\ ${ }^{3}$ Chinese Medicine Resources, China Medical University; ${ }^{4}$ Department of Surgery, China Medical University Hospital, \\ Taichung 404; ${ }^{5}$ International Master's Degree Program in Food Science, International College, \\ National Pingtung University of Science and Technology, Pingtung 912; ${ }^{6}$ School of Pharmacy, \\ ${ }^{7}$ Department of Physiology and ${ }^{8}$ School of Medicine, China Medical University, Taichung 404; \\ ${ }^{9}$ Department of Medical Laboratory Science and Biotechnology, College of Medicine and Life Science, \\ Chung Hwa University of Medical Technology, Tainan 717; ${ }^{10}$ Department of Surgery, \\ China Medical University Beigang Hospital, Beigang, Yunlin 651; ${ }^{11}$ Department of Biotechnology,
}

Asia University, Wufeng, Taichung 413, Taiwan, R.O.C.

Received May 24, 2016; Accepted October 20, 2017

DOI: $10.3892 / \mathrm{ol} .2018 .8286$

\begin{abstract}
Tetrandrine (TET) exhibits biological activities, including anticancer activity. In Chinese medicine, TET has been used to treat hypertensive and arrhythmic conditions and has been demonstrated to induce cytotoxic effects on human cancer cell lines. However, to the best of the author's knowledge, no previous studies have revealed that TET affects cell metastasis in SW620 human colon cancer cells. The present study demonstrated that TET decreased the cell number and inhibited cell adhesion and mobility of SW620 cells. Furthermore, a wound healing assay was performed to demonstrate that TET suppressed cell movement, and Transwell chamber assays were used to reveal that TET suppressed the cell migration and invasion of SW620 cells. Western blotting demonstrated that TET significantly reduced protein expression levels of SOS Ras/Rac
\end{abstract}

Correspondence to: Professor Jing-Gung Chung, Department of Biological Science and Technology, China Medical University, 91 Hsueh-Shih Road, Taichung 404, Taiwan, R.O.C.

E-mail: jgchung@mail.cmu.edu.tw

Dr Kuang-Chi Lai, Department of Surgery, China Medical University Beigang Hospital, 123 Xinde Road, Beigang, Yunlin 651, Taiwan, R.O.C.

E-mail: kuangchi_lai@hotmail.com

Key words: tetrandrine, migration, invasion, matrix metalloproteinase-2, matrix metalloproteinase-9, nuclear factor- $\kappa \mathrm{B}$ p65, SW620 human colon cancer cells guanine nucleotide exchange factor 1, phosphatidylinositol 3-kinase, growth factor receptor bound protein 2, phosphorylated (p)-c Jun N-terminal kinase 1/2, p-p38, p38, 14-3-3, Rho A, $\beta$-catenin, nuclear factor- $\kappa \mathrm{B}$ p65, signal transducer and activator of transcription-1 and cyclooxygenase-2, in comparison with untreated SW620 cells. Overall, the results of the present study suggested that TET may be used as a novel anti-metastasis agent for the treatment of human colon cancer in the future.

\section{Introduction}

In recent years, colorectal cancer remains a primary cause of morbidity and it is the fourth leading cause of cancer-associated mortality worldwide (1). In the USA (2) and Europe (3), colorectal cancer is the second leading cause of cancer-associated mortality. In China, it has been noted that the morbidity and mortality rates of colorectal cancer were increased compared with previous years (4). In Taiwan, colon cancer is the fourth most common type of cancer, accounting for 23.9 mortalities per 100,000 individuals, based on the 2014 report from the Department of Health, Executive Yuan, Taiwan (5). For patients with superficial cancer (Duke's staging of colorectal cancer), the 5-year survival rate was up to $90 \%$; however, for patients with distant metastasis, the survival rate was $\sim 9 \%(6,7)$. Therefore, it is well known that investigating the mechanisms underlying metastatic disease is critical for the treatment and development of metastatic prevention strategies of patients with cancer.

It is well known that tumor metastasis involves epithelial cancer cell adhesion, migration, invasion and angiogenesis for the development of cancer in other sites of the body $(8,9)$. 
Furthermore, numerous factors are associated with tumor metastasis, including matrix metalloproteinases (MMPs) and urokinase plasminogen activator (uPA), which serve critical roles in degrading the extracellular matrix and basement membrane collagen for cancer cells to invade into new sites (10-12). Epithelial mesenchymal-transition (EMT) is an important process for epithelial cancer cell loss of polarity and cell to cell contact (13), and EMT is one of the initial and primary events in tumor progression (14). The fibroblast growth factor family has been revealed to be associated with tumor metastasis in EMT $(15,16)$. Other factors, including secreted factors, cytokines, chemokines and growth factors have been revealed to be associated with the distinct modes of metastasis and subsequent mortality in tumors (17). A previous study demonstrated that activation of the phosphatidylinositol 3 kinase (PI3K)/protein kinase B (Akt) signaling pathway is involved in cancer cell metastasis (18). Therefore, numerous studies have aimed to investigate the use of novel compounds extracted from natural products as treatments for colon cancer cell metastasis (19-21).

Tetrandrine (TET), a bisbenzylisoquinoline alkaloid isolated from the root of Stephania tetrandra S. Moore, has been revealed to have biological activity, including cytotoxic effects, cell cycle arrest and induction of cell apoptosis in a number of human cancer cell lines (22-26). It was reported that TET suppresses proliferation, induces apoptosis and inhibits migration and invasion in human prostate cancer cells (27). It was also reported that TET regulates metastatic- and angiogenic-associated proteins, including vascular endothelial growth factor, hypoxia-inducible factor-1, integrin $\beta 5$, endothelial cell specific molecule-1 and intercellular adhesion molecule-1 (28). Previously, it was demonstrated that TET targets epidermal growth factor receptor signaling and its downstream molecules contribute to the inhibition of epidermal growth factor (EGF)-induced HT29 cell metastasis in vitro (29). Furthermore, it was also reported that TET-loaded PVP-b-PCL nanoparticles more efficiently inhibit cell migration and invasion compared with free TET in A549 human lung cancer cells (30). Although it was reported that TET inhibits cell migration and invasion in human colon cancer HT29 cells via inhibition of EGF, whether nuclear factor $(N F)-\kappa B$ is involved in TET suppression of SW620 human colon cancer cell metastasis remains unclear. The present study revealed that TET inhibited cell migration and invasion of SW620 cells via the $\mathrm{PI} 3 \mathrm{~K}, \mathrm{NF}-\mathrm{\kappa} \mathrm{B}$ and mitogen-activated protein kinase signaling pathways.

\section{Materials and methods}

Chemicals and reagents. TET, dimethyl sulfoxide (DMSO) and propidium iodide were obtained from Sigma-Aldrich (Merck KGaA, Darmstadt, Germany). Leibovitz's L-15 medium, fetal bovine serum(FBS),L-glutamine and antibiotics (penicillin-streptomycin) were purchased from Gibco (Thermo Fisher Scientific, Inc., Waltham, MA, USA). Primary and secondary antibodies were obtained from Cell Signaling Technology, Inc. (Danvers, MA, USA). Polyvinylidene difluoride (PVDF) membrane was obtained from EMD Millipore (Billerica, CA, USA).

Cell culture. The SW620 human colon cancer cell line was purchased from the Food Industry Research and Development Institute (Hsinchu, Taiwan). Cells were cultured in Leibovitz's
L-15 medium supplemented with 10\% FBS, 100 units/ml penicillin and $100 \mu \mathrm{g} / \mathrm{ml}$ streptomycin in a $75 \mathrm{~cm}^{2}$ tissue culture flask at $37^{\circ} \mathrm{C}$ in a humidified atmosphere containing $5 \%$ $\mathrm{CO}_{2}(31,32)$.

Cell viability assays. SW620 cells were seeded in a 96-well plate at a density of $1.5 \times 10^{4}$ cells/well and treated with TET at the final concentrations of $0,0.2,0.39,0.78,1.56,3.12,6.25$, $12.5,25$ and $50 \mu \mathrm{M}$ or $0.5 \%$ DMSO as the vehicle control. Following exposure to the drug for 24 or $48 \mathrm{~h}, 100 \mu \mathrm{l}$ MTT $(0.5 \mathrm{mg} / \mathrm{ml}$; Sigma-Aldrich; Merck KGaA) was added to each well and the plates were incubated for an additional $4 \mathrm{~h}$ at $37^{\circ} \mathrm{C}$. MTT solution in the medium was aspirated off. To achieve solubilization of the formazan crystals formed in viable cells, $200 \mu 1$ DMSO was added to each well prior to evaluation of absorbance at a wavelength of $570 \mathrm{~nm}$ (33).

Adhesion assay. SW620 cells $\left(1 \times 10^{6}\right.$ cells/well) were cultured with $0,1,5$ and $10 \mu \mathrm{M}$ TET for $48 \mathrm{~h}$ at $37^{\circ} \mathrm{C}$ in 12 -well plates, which were pre-coated with type I collagen $(10 \mu \mathrm{g} / \mathrm{ml})($ Merck KGaA, Darmastadt, Germany) for $60 \mathrm{~min}$ at room temperature. Unattached cells were removed and attached cells were mixed in $1 \%$ glutaraldehyde (Sigma-Aldrich; Merck KGaA) supplemented with PBS for $20 \mathrm{~min}$, and stained with $0.02 \%$ crystal violet solution for $5 \mathrm{~min}$ at room temperature. Ethanol (70\%) was used to dissolve crystal violet in the stained cells. Optical density (O.D.) was evaluated at $570 \mathrm{~nm}$ using a microplate reader with a reference of $405 \mathrm{~nm}$. The adhesion ability (percentage of adhesive cells, \%) was determined by measuring the treated cells compared with the control cells (34).

$$
\text { Adhesion ability (\%) }=\frac{\text { O.D.TET treatment }}{\text { O.D.Control }} \times 100 \%
$$

Wound healing assay. SW620 cells ( $5 \times 10^{5}$ cells/well) were cultured in 6-well plate until cell growth reached $100 \%$ confluence. A sterile yellow micropipette tip was used to scrape the cell monolayers in the well and cells were washed with PBS three times. Cells were then cultured in medium containing $0,1,5$ and $10 \mu \mathrm{M}$ TET for 24 and $48 \mathrm{~h}$ at $37^{\circ} \mathrm{C}$. Cells were examined and imaged using an inverted microscope (x100 magnification) (32,34).

Invasion and migration assays. Evaluation of SW620 cell invasion was performed using Matrigel-coated Transwell cell culture chambers $\left(8 \mu \mathrm{m}\right.$ pore size). Cells $\left(8 \times 10^{4}\right.$ cells/well) were seed in the upper chamber and incubated with Leibovitz's L-15 medium supplemented with $0 \% \mathrm{FBS}$, and 0 or $10 \mu \mathrm{M}$ TET for $48 \mathrm{~h}$ at $37^{\circ} \mathrm{C}$. Leibovitz's L-15 medium supplemented with $10 \%$ FBS was placed in the lower chamber. The non-invaded cells were removed using a cotton swab on the upper surface of the membrane and the invaded cells on the lower surface of the membrane were fixed with $4 \%$ cold formaldehyde, stained with $0.1 \%$ crystal violet for $15 \mathrm{~min}$ at room temperature and then imaged using an inverted light microscope (x200 magnification). The invaded cells in the chamber were counted. For the determination of cell migration, the same invasion assay was performed with the membrane coated without Matrigel, as previously described (34). Cell migration was quantified by ImageJ (version 1.49 o software, National Institutes of Health, 
Bethesda, MD, USA) based on the change in the area of the cell-free gap before and after TET stimulation:

$24 \mathrm{~h}$ Inhibitory ability of Migration (\% of control)

$$
=\left(\frac{\text { would area }_{\text {TET } 24 \mathrm{~h} / \text { would area }} \text { TET } 0 \mathrm{~h}}{\text { would area }_{\text {Control } 24 \mathrm{~h}} / \text { would area }_{\text {Control } 0 \mathrm{~h}}}\right) \times 100 \%
$$

$48 \mathrm{~h}$ Inhibitory ability of Migration ( $\%$ of control)

$$
=\left(\frac{\text { would area }_{\mathrm{TET}} 48 \mathrm{~h} / \text { would area }_{\mathrm{TET}} \mathrm{h}}{\text { would area }_{\text {Control } 48 \mathrm{~h}} / \text { would area }_{\text {Control } 0 \mathrm{~h}}}\right) \times 100 \%
$$

Western blot analysis. SW620 cells $\left(6 \times 10^{6}\right)$ were plated in $10-\mathrm{cm}$ dishes and incubated with $0,1,5,10,20$ and $30 \mu \mathrm{M}$ TET for $48 \mathrm{~h}$ at $37^{\circ} \mathrm{C}$, subsequently the cells were collected and lysed in a lysis buffer [40 mM Tris- $\mathrm{HCl}(\mathrm{pH} 7.4), 10 \mathrm{mM}$ EDTA, $120 \mathrm{mM} \mathrm{NaCl}, 1 \mathrm{mM}$ dithiothreitol, 0.1\% Nonide P-40]. The total protein concentration from each treatment was evaluated as previously described (34). A total of $30 \mu \mathrm{g}$ protein was separated by SDS-PAGE (5\% stacking gel and 10-12\% separation gel) for western blot analysis. The gel was transferred to a PVDF membrane and the membrane was blocked in 5\% fat-free dry milk solution in PBS containing $0.1 \%$ Tween-20 for $1 \mathrm{~h}$ at room temperature, and then incubated with primary antibodies overnight at $4^{\circ} \mathrm{C}$. The phospho-Jun N-terminal kinase (p-JNK) 1/2 (sc-6254), p-38 (sc-136210), phospho-p-38 (sc-166182), ras homolog family member $A$ (Rho A; sc-418), growth factor receptor bound protein 2 (GRB2; sc-503) and 14-3-3 protein $\sigma$ (sc-100638) antibodies were supplied by Santa-Cruz Biotechnology, Inc. (Dallas, TX, USA, dilution 1:1,000). The anti-matrix metalloproteinase (MMP)-1 (MAB13439) and tissue inhibitor of metalloproteinase (TIMP)-1 (AB6007) antibodies were supplies by Merck Millipore Corp. (Billerica, MA, USA; dilution, 1:1,000). The Son of sevenless homolog (SOS)-1 (610095, dilution, 1:250), phosphoinositide 3-kinase (PI3K) (610046, dilution, 1:2,500), signal transducer and activator of transcription 1 (STAT1) (610115, dilution, 1:1,000), cyclooxygenase-2 (Cox-2) (610204, dilution, 1:500) and -nuclear factor kappa B (NF-kB p65) (610868, dilution, 1:500) antibodies were obtained from BD Biosciences (Bedford, MA, USA). The anti-MMP-2 (ab7032, dilution, 1:1,000) antibody was obtained from Abcam (Cambridge, MA, USA), and the MMP-9 (GTX32122, dilution, 1:1,000) antibody was supplied by GeneTex, Inc. (Irvine, CA, USA) for the $\beta$-Catenin (C2206, dilution, 1:4,000) and $\beta$-actin (A5316, dilution, 1:10,000) antibodies were supplied by Sigma-Aldrich (St. Louis, MO, USA). Subsequently, the membranes were incubated with secondary antibodies [horseradish peroxidase (HRP)-conjugated mouse immunoglobulin $\mathrm{G}$ (IgG; GTX213112) and rabbit HRP-conjugated IgG secondary antibodies (GTX213110), dilution, 1:5,000; GeneTex, Irvine, CA, USA] for $1 \mathrm{~h}$ at room temperature. Proteins were visualized using enhanced chemiluminescencereagents (GE Healthcare, Chicago, IL, USA) to stain, as previously described (34).

Statistical analysis. All data are expressed as the mean \pm standard deviation. Differences between groups were analyzed by one-way analysis of variance. Statistical comparisons were made using Tukey's test (SigmaPlot for Windows v12.0; Systat Software, Inc., San Jose, CA), and $\mathrm{P}<0.05$ was considered to indicate a statistically significant difference. Differences between two groups were determined using the unpaired Student's t-test (SigmaPlot for Windows version 10.0; Systat

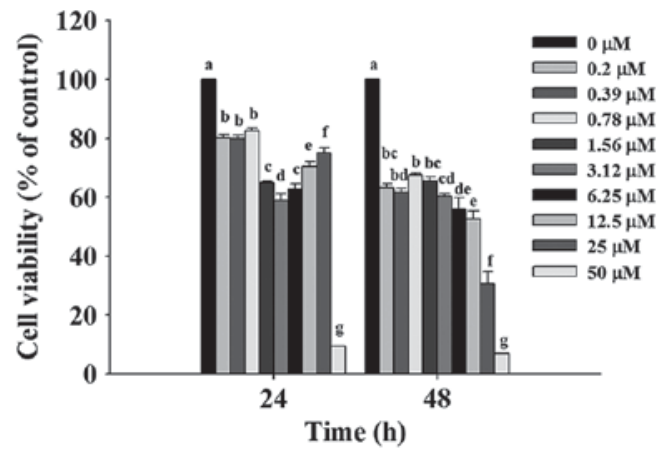

Figure 1. TET decreases the percentage of viable SW620 cells. Cells $\left(1.5 \times 10^{4}\right.$ cells/well $)$ were treated with $0,0.2,0.39,0.78,1.56,3.12,6.25,12.5$, 25 and $50 \mu \mathrm{M}$ TET or $0.5 \%$ dimthylsulfoxide as a vehicle control for 24 and $48 \mathrm{~h}$. Cell growth inhibition was assessed by MTT assay. The values with different letters were significantly different from each other, $\mathrm{P}<0.05$ (Tukey's test). TET, tetrandrine.

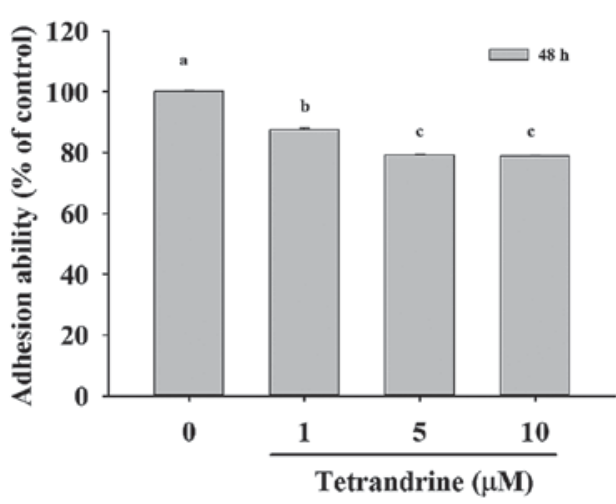

Figure 2. TET decreases the cell adhesion of SW620 cells. SW620 cells were cultured with $0,1,5$ and $10 \mu \mathrm{M}$ TET for $48 \mathrm{~h}$ at $37^{\circ} \mathrm{C}$ in 12 -well plates, which were pre-coated with type I collagen $(10 \mu \mathrm{g} / \mathrm{ml})$ for $60 \mathrm{~min}$, and the attached cells were mixed with $1 \%$ glutaraldehyde in PBS for $20 \mathrm{~min}$ and stained with $0.02 \%$ crystal violet solution for $5 \mathrm{~min}$. Ethanol (70\%) was used to dissolve crystal violet in the stained cells. Optical density was evaluated at $570 \mathrm{~nm}$ using a microplate reader with a reference of $405 \mathrm{~nm}$. The total percentage of adhesion was determined based on the cells that had adhered compared with the control. The results are presented as the mean \pm standard deviation $(n=3)$. The values with different letters were significantly different from each other, $\mathrm{P}<0.05$ (Tukey's test). TET, tetrandrine.

Software, Inc., San Jose, CA), and $\mathrm{P}<0.01$ was considered to indicate a statistically significant difference.

\section{Results}

TET decreases the cell viability of SW620 cells. SW620 cells were treated with TET $(0,0.2,0.39,0.78,1.56,3.12,6.25,12.5$, 25 and $50 \mu \mathrm{M}$ ) for 24 and $48 \mathrm{~h}$ prior to collection of the cells to determine the percentage of total viable cell number (Fig. 1). The data indicated a significant dose-dependent reduction of living SW620 cells treated with TET at $0.2-50 \mu \mathrm{M}$ concentrations for 24 and $48 \mathrm{~h}(\mathrm{P}<0.001)$. Thus the present study selected $0,1,5$ and $10 \mu \mathrm{M}$ for cell migration and invasion experiments.

TET decreases the cell adhesion of SW620 cells. SW620 cells were cultured with $0,1,5$ and $10 \mu \mathrm{M}$ TET for $48 \mathrm{~h}$ and the total percentage of adhesion was determined and presented in Fig. 2, [1 $\mu \mathrm{M}(87.36 \pm 0.71 \%, \mathrm{P}<0.05) ; 5 \mu \mathrm{M}(79.22 \pm 0.18 \%$, 
A
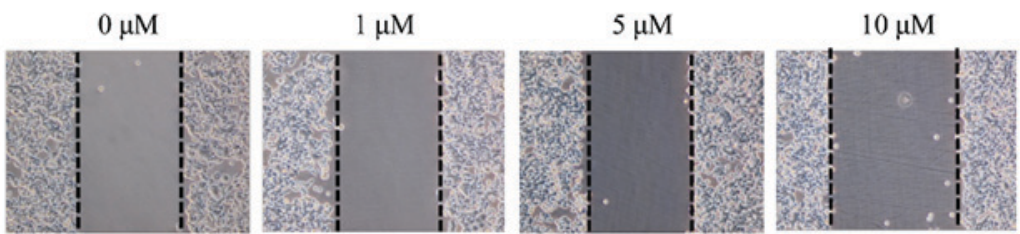

$24 \mathrm{~h}$
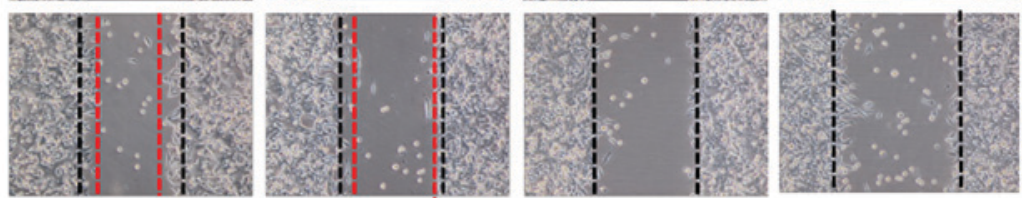

$48 \mathrm{~h}$
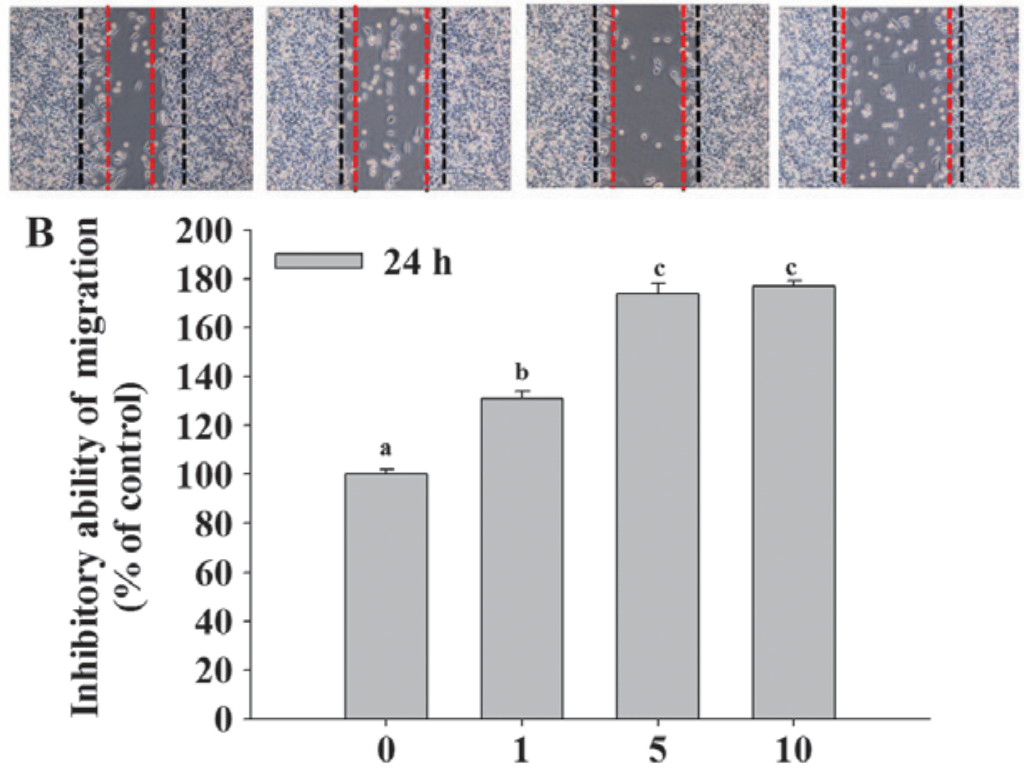

Concentration of tetrandrine $(\mu \mathrm{M})$

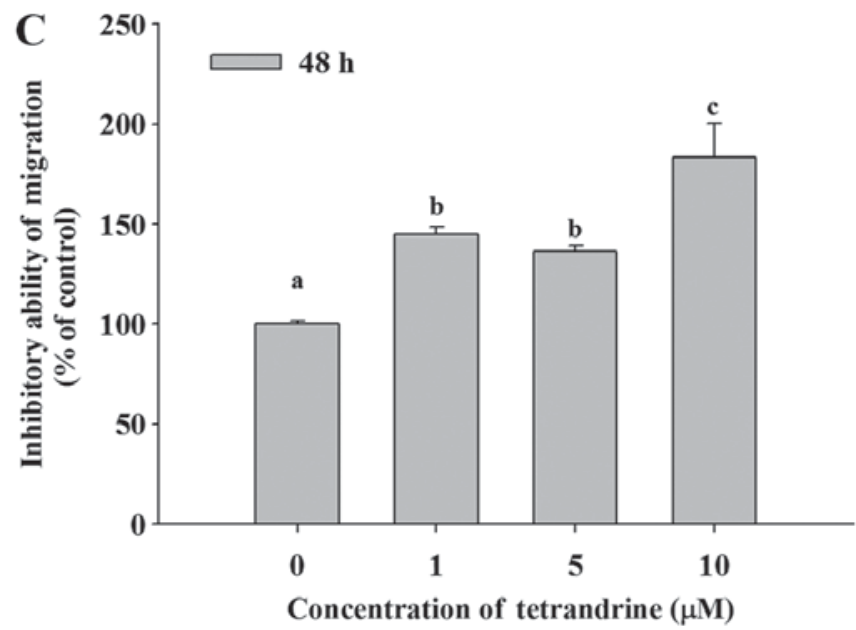

Figure 3. TET decreases cell mobility of SW620 cells. Cell mobility was evaluated using a wound healing assay. SW620 cells were cultured in a 6-well plate, the cell monolayers were scraped and then cultured in medium containing $0,1,5$ and $10 \mu \mathrm{M}$ TET for 24 and $48 \mathrm{~h}$. (A) The cell mobility rates were examined and imaged using contrast phase microscopy (x200 magnification). The (B) $24 \mathrm{~h}$ and (C) $48 \mathrm{~h}$ percentage of inhibition of cell motilities were determined. The values with different letters were significantly different from each other, $\mathrm{P}<0.05$ (Tukey's test). TET, tetrandrine.

$\mathrm{P}<0.05) ; 10 \mu \mathrm{M}(78.72 \pm 0.18 \%, \mathrm{P}<0.05)$ compared to untreated control cells $(100.00 \pm 0.18 \%)]$. Based on these results, it was indicated that TET at $1-10 \mu \mathrm{M}$ for $48 \mathrm{~h}$ treatment significantly reduced cell adhesion in SW620 cells in vitro.

TET decreases cell mobility of SW620 cells. Cell mobility was evaluated using a wound healing assay. SW620 cells were cultured in 6-well plates and the cell monolayers were scraped and then cultured in medium containing $0,1,5$ and $10 \mu \mathrm{M}$ TET for 24 and $48 \mathrm{~h}$ (Fig. 3). Fig. 3A demonstrated that closure of the scraped area at the highest dose of TET was decreased compared with the control. TET significantly reduced cell mobility, and increased the ability to inhibit migration at 24 and $48 \mathrm{~h}$ up to 176.74 and $183.45 \%$ in the 
A
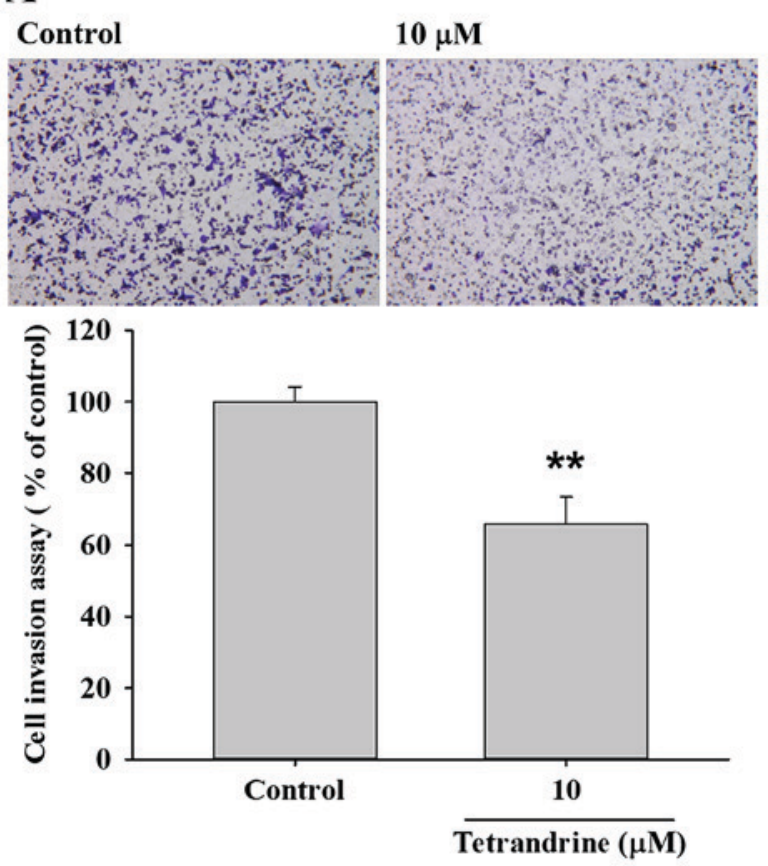

B

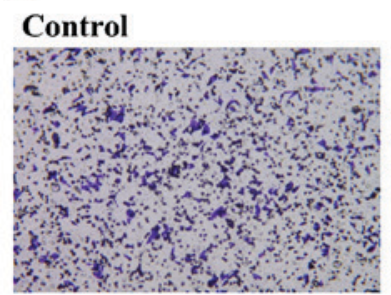

$10 \mu \mathrm{M}$

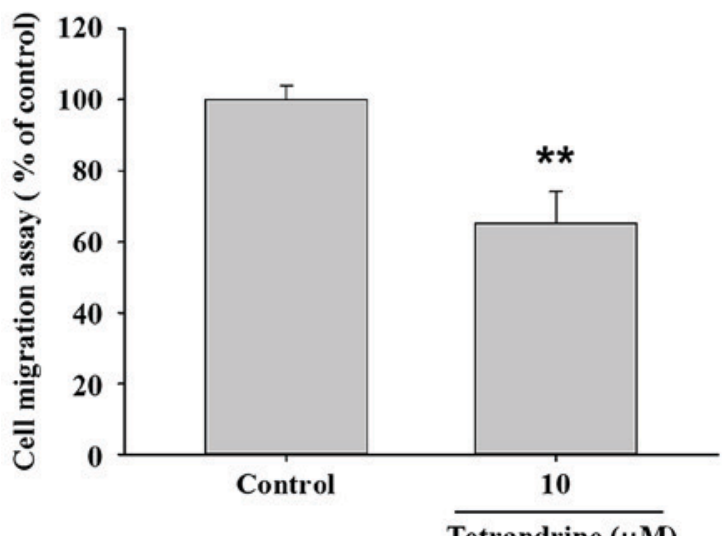

$\overline{\text { Tetrandrine }(\mu \mathrm{M})}$

Figure 4. TET inhibits migration and invasion of SW620 cells. Transwell cell migration and invasion assays were used to investigate the inhibition of TET on SW620 cell migration and invasion. (A) Cell invasion was imaged using contrast phase microscopy (x100 magnification) and percentage of inhibition of cell invasion. (B) Cell migration was imaged using contrast phase microscopy (X100) and percentage of inhibition of cell migration. ${ }^{* *} \mathrm{P}<0.01$ (Student's t-test) vs. control. TET, tetrandrine.

$10 \mu \mathrm{M}$ TET treated cells, respectively, compared with control cells (Fig. 3B and C).

TET inhibits the migration and invasion of SW620 cells. Transwell migration and invasion assays were performed to investigate the inhibitory role of TET on SW620 cell migration and invasion, the results are presented in Fig. 4. The results indicated that TET significantly $(\mathrm{P}<0.05)$ inhibited cell invasion by $35 \%$ for $10 \mu \mathrm{M}$ TET treated cells for $48 \mathrm{~h}(\mathrm{P}<0.01$; Fig. 4A), and inhibited cell migration by $35 \%$ for $10 \mu \mathrm{M}$ TET treated cells for $48 \mathrm{~h}$ compared with the control cells ( $\mathrm{P}<0.01$; Fig. 4B).

TET alters expression levels of proteins associated with migration and invasion of SW620 cells. The present study further investigated the role of upstream regulated proteins associated with SW620 cell migration and invasion following exposure to TET (Fig. 5). TET significantly reduced protein expression levels of MMP-9, MMP-2, MMP-1, SOS Ras/Rac guanine nucleotide exchange factor 1 (SOS-1), PI3K, phosphorylated (p)-c Jun N-terminal kinase (JNK)1/2, growth factor receptor bound protein 2 (GRB2) and TIMP metallopeptidase inhibitor 1 (TIMP1; Fig. 5A), p-p38, p38, 14-3-3, Rho A, signal transducer and activator of transcription-1 (STAT-1) and cyclooxygenase-2 (Cox-2; Fig. 5B), $\beta$-catenin and NF-кB (Fig. 5C). The protein expression levels were decreased in TET-treated cells compared with untreated-cells. TET inhibited the p38, JNK and Rho A signaling pathways by reducing PI3K, Cox-2 and NF- $\mathrm{B}$ p 65 expression levels, which induced MMP-2/-9 downregulation (Fig. 6).

\section{Discussion}

Previous studies have demonstrated that cancer cells exhibit extensive invasive and migratory abilities, which are factors that may block the effectiveness of clinical treatments against cancer, including chemotherapy $(35,36)$. Cancer cell metastasis involves a complex multistep process, which includes cell movement and cell adhesion accompanied with migration, invasion and angiogenesis to develop new tumors in other sites of body $(37,38)$. Therefore, investigators focus on the inhibition of cancer cell migration and invasion, as an anticancer strategy. It has previously been reported that TET induces cancer cell death via cell cycle arrest and induction of apoptosis in numerous human cancer cell lines; however, there is no available information to demonstrate TET inhibiting migration and invasion in human colon cancer SW620 cells. The present study investigated the effects of TET on adhesion, migration and invasion of SW620 cells in vitro.

Firstly, the present study examined the cytotoxic effects of TET on SW620 cells in vitro and the results indicated that TET induced cell death in a dose-dependent manner. Therefore, 1,5 and $10 \mu \mathrm{M}$ TET treatments were selected for further experiments. The present study also investigated cell adhesion of SW620 cells following exposure to $0,1,5$ and $10 \mu \mathrm{M}$ TET for $48 \mathrm{~h}$ and the results indicated that TET inhibited cell adhesion in a concentration-dependent manner. It is well documented that wound healing is one of the methods for examining cancer cell mobility $(39,40)$; thus, the results from the wound healing assay indicated that TET inhibited cell mobility in SW620 cells in a dose-dependent manner. The Transwell assay has been recognized to be effective in the analysis of cell migration and invasion $(41,42)$. The present study performed Transwell assays to investigate cell migration and invasion of SW620 cells following exposure to TET in vitro. The findings indicated that TET significantly inhibited cell migration and invasion when compared with the control groups. Based on these observations, the present study suggested that TET suppressed cell migration 

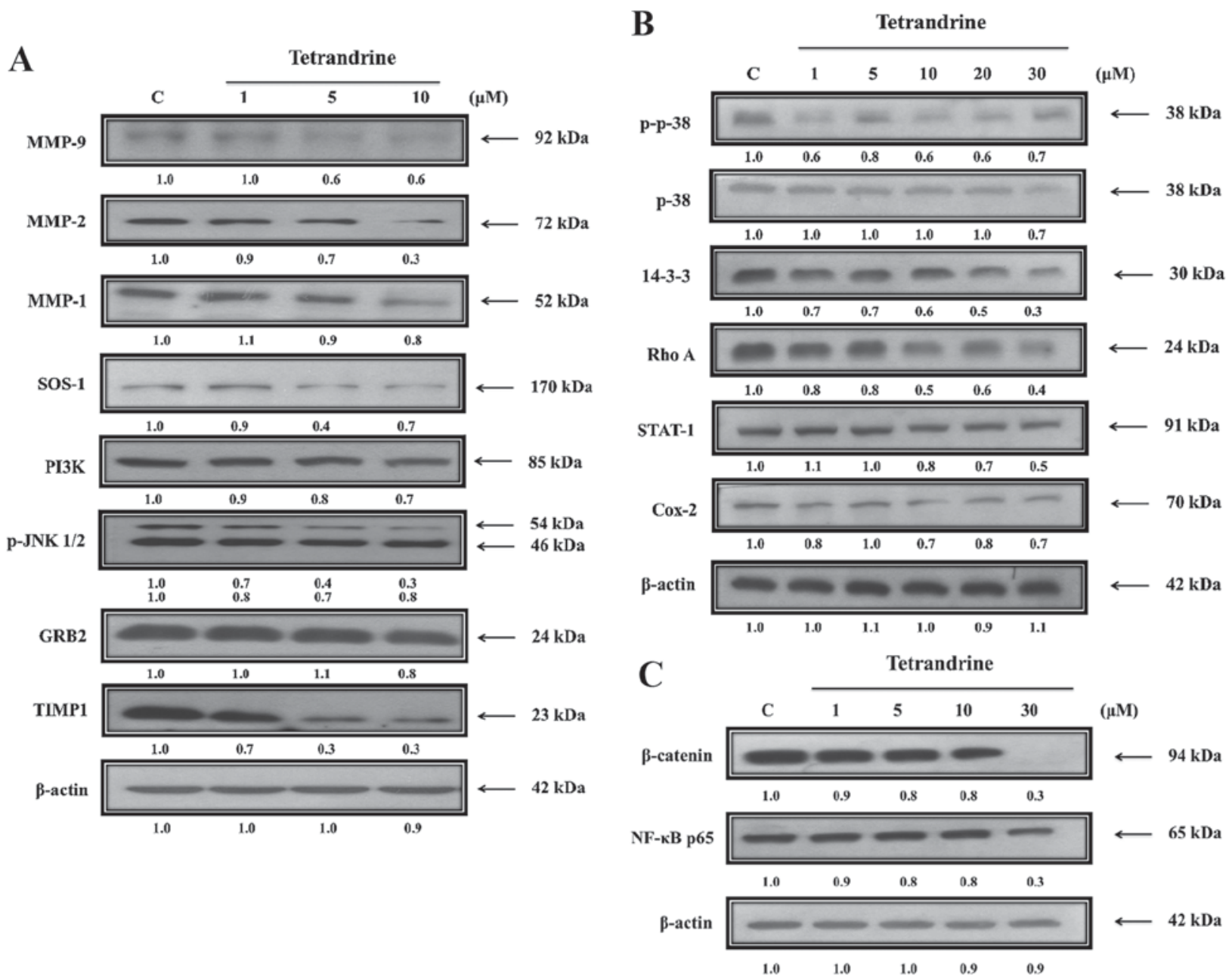

Figure 5. TET alters the expression levels of proteins associated with migration and invasion of SW620 cells. Cells were treated with various concentrations of TET for $48 \mathrm{~h}$ and then total proteins were quantified and apoptosis associated proteins were examined by western blotting. (A) MMP-9, MMP-2 and MMP-1, SOS-1, PI3K, p-JNK1/2, GRB2, TIMP1. (B) p-p38, p38, 14-3-3, Rho A, STAT-1 and Cox-2. (C) $\beta$-catenin and NF-кB p65. TET, tetrandrine. MMP, matrix metalloproteinase; SOS-1, SOS Ras/Rac guanine nucleotide exchange factor 1; PI3K, phosphatidylinositol 3 kinase; p, phosphorylated; JNK1/2, c Jun N-terminal kinase; GRB2, growth factor receptor bound protein 2; TIMP1, TIMP metallopeptidase inhibitor 1; STAT-1, signal transducer and activator of

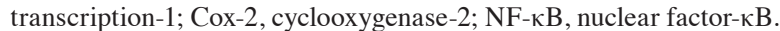

and invasion via the inhibition of cell attachment (adhesion) to the basement membrane.

MMPs, a family of zinc-dependent proteases, serve essential roles in defining how cells interact with their surrounding microenvironment (43). It was reported that increased expression levels of MMPs are associated with increased levels of cancer cell angiogenesis, migration and invasion (44); thus, MMPs have previously been used as drug targets (45). Therefore, the present study first examined the protein expression levels of MMP-2 and MMP-9 in SW620 cells following exposure to various concentrations of TET, and the results indicated that TET decreased the protein expression levels of MMP-2, MMP-9, MMP-1 and TIMP1 in a concentration-dependent manner, which was revealed by western blotting. MMP-2 and MMP-9 serve important roles in cancer invasion and metastasis $(46,47)$. Furthermore, results indicated that TET suppressed the protein expression levels of SOS-1, PI3K, GRB2 and p-JNK1/2 in SW620 cells. SOS-1 and GRB2 have been observed in HT 29 colon cancer cells (48). To the best of the author's knowledge, the present study is the first demonstrate that TET inhibited the protein expression levels of SOS-1 and GRB2. GRB2-associated binding protein 2 serves a

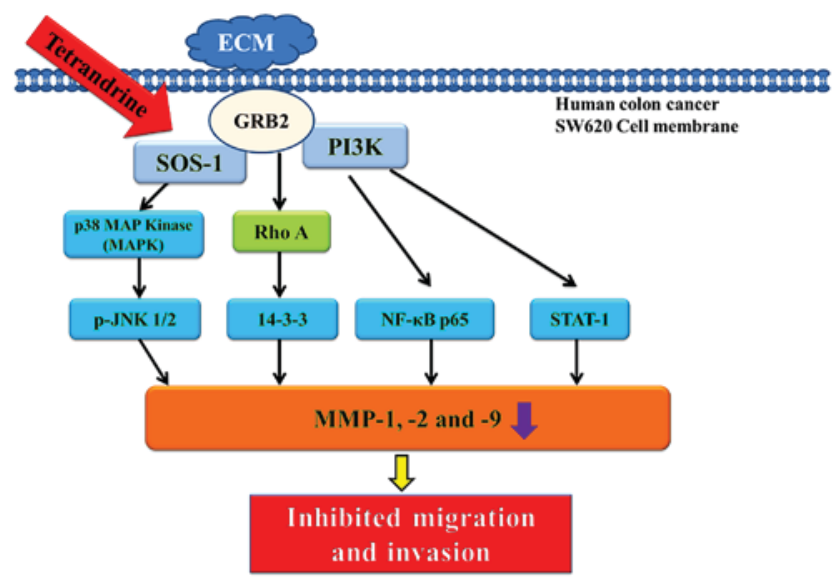

Figure 6 . The possible signaling pathways for TET inhibited cell mobility, adhesion, migration and invasion in SW620 cells in vitro. TET, tetrandrine; ECM, extracellular matrix; GRB2, growth factor receptor bound protein 2; SOS-1, SOS Ras/Rac guanine nucleotide exchange factor 1; PI3K, phosphatidylinositol 3 kinase; p, phosphorylated; JNK1/2, c Jun N-terminal

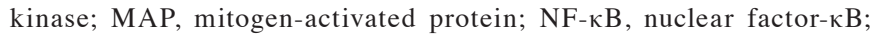
STAT-1, signal transducer and activator of transcription-1; MMP, matrix metalloproteinase. 
critical role in the proliferation and migration of various types of cancer (49). Therefore, further investigations are required to understand the role of SOS-1 and GRB2 in cancer cell metastasis. The results of the present study also revealed that TET inhibited the protein expression levels of PI3K in SW620 cells. PI3K/Akt and extracellular signal regulated kinase pathways are involved in growth factor-mediated colon cancer proliferation (50). It was reported that $17 \beta$-estradiol treatment inhibited prostaglandin E2-induced uPA, MMP-9 and cellular motility by suppressing activation of JNK1/2 in LoVo human colon cancer cells (51).

The results of the present study demonstrated that TET inhibited the protein expression levels of p-p38, p38, 14-3-3 and Rho A in SW620 cells. p-p38 and p38 were significantly reduced in TET-treated SW620 cells compared with untreated cells. It was previously reported that in SW620 human colon cancer-derived metastatic cells, nicotine stimulates the invasion and metastasis of colon cancer cells in vitro via activation of the p38 MAPK downstream signaling pathway (52). The present study revealed that TET significantly reduced the protein expression levels of 14-3-3 in SW620 cells in a dose-dependent manner. It was previously demonstrated that 14-3-3 protein overexpression promotes lung cancer progression when combined with HSP27 overexpression (53). A previous study revealed that in patient colorectal cancer samples, Rho A is associated with the invasion of lymph nodes and blood vessels, thus, Rho A may be a promising target for cancer treatment (54).

The results of the present study additionally indicated that TET significantly suppressed the protein expression levels of $\beta$-catenin and NF- $\mathrm{kB}$ p65 in SW620 cells. $\beta$-catenin is a 92-kDa cellular protein and a member of the Wnt signaling pathway that has been revealed to serve an important role in colorectal cancer tumorigenesis $(55,56)$, and is associated with E-cadherin in maintaining cellular adhesion (57). The aberrant activation of $\beta$-catenin increases its translocation to the nucleus in colorectal cancer (58). Therefore, targeting the Wnt/ $\beta$-catenin signaling pathway to develop novel chemotherapeutic agents against colon cancer may be a promising strategy. NF- $\mathrm{KB}$ is a transcription factor closely associated with cell survival, proliferation and metastasis (59). It is well documented that agents blocking the NF- $\mathrm{kB}$ signaling pathway may act as therapeutic agents to treat inflammation and cancer (60). The results of the present study indicated that TET inhibited cell migration and invasion of SW620 cells via inhibition of NF- $\mathrm{KB}$. It was also revealed that TET suppressed the protein expression levels of STAT1 and Cox-2 in SW620 cells. Constitutive overexpression of STAT1 in tumor cells is correlated with protection of tumor cells to genotoxic stress following doxorubicin (61) or cisplatin (62) treatment. Cox-2 has tumor promoting properties and is expressed in approximately $40-50 \%$ of colonic adenomas and in $80-90 \%$ of colorectal carcinomas $(63,64)$. Cox-2 is also associated with cancer cell invasion (65), serves an important role in carcinogenesis and therefore has the potential to be used as a novel anticancer therapeutic target $(66,67)$.

In conclusion, the present study revealed that TET suppressed cell mobility, adhesion, invasion and migration in SW620 cells via the inhibition of metastasis-associated proteins such as MMP-2/-9.

Therefore, the results of the present study suggested that TET may be a potential candidate for developing preventive agents against human colon cancer metastasis.

\section{Acknowledgements}

The present study was supported by the China Medical University Beigang Hospital, Yunlin, Taiwan (grant no. CMUBH R103-011).

\section{Competing interests}

The authors declare that they have no competing interests.

\section{References}

1. Siegel R, Desantis C and Jemal A: Colorectal cancer statistics, 2014. CA Cancer J Clin 64: 104-117, 2014.

2. Labianca R, Beretta GD, Kildani B, Milesi L, Merlin F, Mosconi S, Pessi MA, Prochilo T, Quadri A, Gatta G, et al: Colon cancer. Crit Rev Oncol Hematol 74: 106-133, 2010.

3. Ferlay J, Parkin DM and Steliarova-Foucher E: Estimates of cancer incidence and mortality in Europe in 2008. Eur J Cancer 46: 765-781, 2010.

4. Li M and $\mathrm{Gu} \mathrm{J}$ : Changing patterns of colorectal cancer in China over a period of 20 years. World J Gastroenterol 11: 4685-4688, 2005.

5. Ministry of Health and Welfare: The cancer mortality report of the Department of Health, Taiwan, 2014.

6. Camp ER and Ellis LM: CCR 20th Anniversary Commentary: RAS as a Biomarker for EGFR-targeted therapy for colorectal cancer-from concept to practice. Clin Cancer Res 21: 3578-3580, 2015.

7. Siegel R, Ma J, Zou Z and Jemal A: Cancer statistics, 2014. CA Cancer J Clin 64: 9-29, 2014.

8. Hazan RB, Qiao R, Keren R, Badano I and Suyama K: Cadherin switch in tumor progression. Ann N Y Acad Sci 1014: 155-163, 2004.

9. Makrilia N, Kollias A, Manolopoulos L and Syrigos K: Cell adhesion molecules: Role and clinical significance in cancer. Cancer Invest 27: 1023-1037, 2009.

10. Babykutty S, Suboj P, Srinivas P, Nair AS, Chandramohan K and Gopala $S$ : Insidious role of nitric oxide in migration/invasion of colon cancer cells by upregulating MMP-2/9 via activation of cGMP-PKG-ERK signaling pathways. Clin Exp Metastasis 29: 471-492, 2012.

11. Dung TD,Feng CC, Kuo WW, Pai P, Chung LC, Chang SH, Hsu HH, Tsai FJ, Lin YM and Huang CY: Suppression of plasminogen activators and the MMP-2/-9 pathway by a Zanthoxylum avicennae extract to inhibit the HA22T human hepatocellular carcinoma cell migration and invasion effects in vitro and in vivo via phosphatase $2 \mathrm{~A}$ activation. Biosci Biotechnol Biochem 77: 1814-1821, 2013.

12. Liotta LA, Tryggvason K, Garbisa S, Hart I, Foltz CM and Shafie S: Metastatic potential correlates with enzymatic degradation of basement membrane collagen. Nature 284: 67-68, 1980.

13. Lamouille S, Xu J and Derynck R: Molecular mechanisms of epithelial-mesenchymal transition. Nat Rev Mol Cell Biol 15: 178-196, 2014.

14. Kalluri R: EMT: When epithelial cells decide to become mesenchymal-like cells. J Clin. Invest 119: 1417-1419, 2009.

15. Acloque H, Adams MS, Fishwick K, Bronner-Fraser M and Nieto MA: Epithelial-mesenchymal transitions: The importance of changing cell state in development and disease. J Clin Invest 119: 1438-1449, 2009.

16. Kortylewski M, Xin H, Kujawski M, Lee H, Liu Y, Harris T, Drake C, Pardoll D and Yu H: Regulation of the IL-23 and IL-12 balance by Stat 3 signaling in the tumor microenvironment. Cancer Cell 15: 114-123, 2009.

17. Hanahan D and Weinberg RA: Hallmarks of cancer: The next generation. Cell 144: 646-674, 2011.

18. Rieger-Christ KM, Lee P,Zagha R, Kosakowski M, Moinzadeh A, Stoffel J, Ben-Ze'ev A, Libertino JA and Summerhayes IC: Novel expression of N-cadherin elicits in vitro bladder cell invasion via the Akt signaling pathway. Oncogene 23: 4745-4753, 2004.

19. Tong W, Wang Q, Sun D and Suo J: Curcumin suppresses colon cancer cell invasion via AMPK-induced inhibition of NF- $\kappa$, uPA activator and MMP9. Oncol Lett 12: 4139-4146, 2016.

20. Han M, Song Y and Zhang X: Quercetin suppresses the migration and invasion in human colon cancer Caco-2 cells through regulating toll-like receptor 4/nuclear factor-kappa B Pathway. Pharmacogn Mag 12 (Suppl 2): S237-S244, 2016.

21. Yun JH, Kim KA, Yoo G, Kim SY, Shin JM, Kim JH, Jung SH, Kim J and Nho CW: Phenethyl isothiocyanate suppresses cancer stem cell properties in vitro and in a xenograft model. Phytomedicine 30: 42-49, 2017. 
22. Kuo PL and Lin CC: Tetrandrine-induced cell cycle arrest and apoptosis in Hep G2 cells. Life Sci 73: 243-252, 2003.

23. Lee JH, Kang GH, Kim KC, Kim KM, Park DI, Choi BT, Kang HS, Lee YT and Choi YH: Tetrandrine-induced cell cycle arrest and apoptosis in A549 human lung carcinoma cells. Int J Oncol 21: 1239-1244, 2002.

24. Meng LH, Zhang H, Hayward L, Takemura H, Shao RG and Pommier Y: Tetrandrine induces early G1 arrest in human colon carcinoma cells by down-regulating the activity and inducing the degradation of G1-S-specific cyclin-dependent kinases and by inducing p53 and p21Cip1. Cancer Res 64: 9086-9092, 2004.

25. Chen XL, Ren KH, He HW and Shao RG: Involvement of $\mathrm{PI} 3 \mathrm{~K} / \mathrm{AKT} / \mathrm{GSK} 3$ beta pathway in tetrandrine-induced G1 arrest and apoptosis. Cancer Biol Ther 7: 1073-1078, 2008.

26. McCubrey JA,Basecke J, Cervello M, Martelli AM and Franklin RA: GSK-3beta is a critical mediator of tetrandrine induced cell cycle arrest and cytotoxicity. Cancer Biol Ther 7: 1079, 2008.

27. Liu W, Kou B, Ma ZK, Tang XS, Lv C, Ye M, Chen JQ, Li L, Wang XY and He DL: Tetrandrine suppresses proliferation, induces apoptosis, and inhibits migration and invasion in human prostate cancer cells. Asian J Androl 17: 850-853, 2015.

28. Gao JL, Ji X, He TC, Zhang Q, He K, Zhao Y, Chen SH and Lv GY: Tetrandrine suppresses cancer angiogenesis and metastasis in 4T1 tumor bearing mice. Evid Based Complement. Alternat Med 2013: 265061, 2013

29. Horng CT, Yang JS, Chiang JH, Lu CC, Lee CF, Chiang NN and Chen FA: Inhibitory effects of tetrandrine on epidermal growth factor-induced invasion and migration in HT29 human colorectal adenocarcinoma cells. Mol Med Rep 13: 1003-1009, 2016.

30. Xu H, Hou Z, Zhang H, Kong H, Li X, Wang H and Xie W: An efficient Trojan delivery of tetrandrine by poly(N-vinylpyrr olidone)-block-poly( $\varepsilon$-caprolactone) (PVP-b-PCL) nanoparticles shows enhanced apoptotic induction of lung cancer cells and inhibition of its migration and invasion. Int $\mathbf{J}$ Nanomedicine 9: 231-242, 2014

31. Zhang JS, Li DM, Ma Y, He N, Gu Q, Wang FS, Jiang SQ, Chen BQ and Liu JR: $\gamma$-Tocotrienol induces paraptosis-like cell death in human colon carcinoma SW620 cells. PLoS One 8 e57779, 2013

32. Chang YM, Velmurugan BK, Kuo WW, Chen YS, HO TJ, Tsai CT, Ye CX, Tsai CH, Tsai FJ and Huang CY: Inhibitory effect of alpinate Oxyphyllae fructus extracts on Ang II-induced cardiac pathological remodeling-related pathways in $\mathrm{H} 9 \mathrm{c} 2$ cardiomyoblast cells. Biomedicine 3: 148-152, 2013.

33. Park WH, Seol JG, Kim ES, Hyun JM, Jung CW, Lee CC Kim BK and Lee YY: Arsenic trioxide-mediated growth inhibition in MC/CAR myeloma cells via cell cycle arrest in association with induction of cyclin-dependent kinase inhibitor, p21, and apoptosis. Cancer Res 60: 3065-3071, 2000.

34. Lai KC, Hsu SC, Yang JS, Yu CC, Lein JC and Chung JG: Diallyl trisulfide inhibits migration, invasion and angiogenesis of human colon cancer HT-29 cells and umbilical vein endothelial cells, and suppresses murine xenograft tumour growth. J Cell Mol Med 19: 474-484, 2015

35. Verhoeff JJ, van Tellingen O, Claes A, Stalpers LJ, van Linde ME, Richel DJ, Leenders WP and van Furth WR: Concerns about anti-angiogenic treatment in patients with glioblastoma multiforme. BMC Cancer 9: 444, 2009.

36. Cheng SH, Jian JJ, Tsai SY, Chan KY, Yen LK, Chu NM, Tan TD, Tsou MH and Huang AT: Prognostic features and treatment outcome in locoregionally advanced nasopharyngeal carcinoma following concurrent chemotherapy and radiotherapy. Int J Radiat Oncol Biol Phys 41: 755-762, 1998.

37. Gupta GP and Massague J: Cancer metastasis: Building a framework. Cell 127: 679-695, 2006.

38. Huang YL, Chu YL, Ho CT, Chung JG, Lai CI, Su YC, Kuo YH and Sheen LY: Antcin K, an active triterpenoid from the fruiting bodies of basswood-cultivated antrodia cinnamomea, inhibits metastasis via suppression of integrin-mediated adhesion, migration, and invasion in human hepatoma cells. J Agric Food Chem 63: 4561-4569, 2015.

39. Park SJ, Kong HK, Kim YS, Lee YS and Park JH: Inhibition of S-adenosylhomocysteine hydrolase decreases cell mobility and cell proliferation through cell cycle arrest. Am J Cancer Res 5: 2127-2138, 2015.

40. Wu ZY, Lien JC, Huang YP, Liao CL, Lin JJ, Fan MJ, Ko YC, Hsiao YP, Lu HF and Chung JG: Casticin inhibits A375.S2 human melanoma cell migration/invasion through downregulating NF- $\kappa \mathrm{B}$ and matrix metalloproteinase-2 and -1 . Molecules 21 : $384,2016$.
41. Ji BC, Hsiao YP, Tsai CH, Chang SJ, Hsu SC, Liu HC, Huang YP, Lien JC and Chung JG: Cantharidin impairs cell migration and invasion of A375.S2 human melanoma cells by suppressing MMP-2 and -9 through PI3K/NF- $\kappa \mathrm{B}$ signaling pathways. Anticancer Res 35: 729-738, 2015.

42. Liao CL, Lai KC, Huang AC, Yang JS, Lin JJ, Wu SH, Gibson Wood W, Lin JG and Chung JG: Gallic acid inhibits migration and invasion in human osteosarcoma U-2 OS cells through suppressing the matrix metalloproteinase-2/-9, protein kinase B (PKB) and PKC signaling pathways. Food Chem Toxicol 50: 1734-1740, 2012

43. Kessenbrock K, Plaks V and Werb Z: Matrix metalloproteinases: Regulators of the tumor microenvironment. Cell 141: 52-67, 2010

44. Shia CS, Suresh G, Hou YC, Lin YC, Chao PD and Juang SH: Suppression on metastasis by rhubarb through modulation on MMP-2 and uPA in human A549 lung adenocarcinoma: An ex vivo approach. J Ethnopharmacol 133: 426-433, 2011.

45. Bauvois B: New facets of matrix metalloproteinases MMP-2 and MMP-9 as cell surface transducers: Outside-in signaling and relationship to tumor progression. Biochim Biophys Acta 1825: 29-36, 2012.

46. Birkedal-Hansen H, Moore WG, Bodden MK, Windsor LJ, Birkedal-Hansen B, DeCarlo A and Engler JA: Matrix metalloproteinases: A review. Crit Rev Oral Biol Med 4: 197-250, 1993.

47. Dutta A, Li J, Lu H, Akech J, Pratap J, Wang T, Zerlanko BJ, FitzGerald TJ, Jiang Z, Birbe R, et al: Integrin $\alpha \mathrm{v} \beta 6$ promotes an osteolytic program in cancer cells by upregulating MMP2. Cancer Res 74: 1598-1608, 2014.

48. Lai KC, Hsu SC, Kuo CL, Ip SW, Yang JS, Hsu YM, Huang HY, Wu SH and Chung JG: Phenethyl isothiocyanate inhibited tumor migration and invasion via suppressing multiple signal transduction pathways in human colon cancer HT29 cells. J Agric Food Chem 58: 11148-11155, 2010.

49. Matsumura T, Sugimachi K, Takahashi Y, Uchi R, Sawada G, Ueda M, Hirata H, Sakimura S, Ueo H, Takano Y, et al: Clinical significance of GAB2, a scaffolding/docking protein acting downstream of EGFR in human colorectal cancer. Ann Surg Oncol 21 (Suppl 4): S743-S749, 2014.

50. Waseem T, Duxbury M, Ashley SW and Robinson MK: Ghrelin promotes intestinal epithelial cell proliferation through PI3K/Akt pathway and EGFR trans-activation both converging to ERK 1/2 phosphorylation. Peptides 52: 113-121, 2014.

51. Hsu HH, Hu WS, Lin YM, Kuo WW, Chen LM, Chen WK, Hwang JM, Tsai FJ, Liu CJ and Huang CY: JNK suppression is essential for $17 \beta$-estradiol inhibits prostaglandin E2-induced uPA and MMP-9 expressions and cell migration in human LoVo colon cancer cells. J Biomed Sci 18: 61, 2011.

52. Xiang T, Fei R, Wang Z, Shen Z, Qian J and Chen W: Nicotine enhances invasion and metastasis of human colorectal cancer cells through the nicotinic acetylcholine receptor downstream p38 MAPK signaling pathway. Oncol Rep 35: 205-210, 2016.

53. Zhao GY, Ding JY, Lu CL, Lin ZW and Guo J: The overexpression of 14-3-3 5 and Hsp27 promotes non-small cell lung cancer progression. Cancer 120: 652-663, 2014

54. Jeong D, Park S, Kim H, Kim CJ, Ahn TS, Bae SB, Kim HJ, $\mathrm{Kim} \mathrm{TH}, \mathrm{Im} \mathrm{J}$ and Lee MS: RhoA is associated with invasion and poor prognosis in colorectal cancer. Int J Oncol 48: 714-722, 2016.

55. Clevers H: Wnt $/ \beta$-catenin signaling in development and disease. Cell 127: 469-480, 2006.

56. White BD, Chien AJ and Dawson DW: Dysregulation of Wnt $/ \beta$-catenin signaling in gastrointestinal cancers. Gastroenterology 142: 219-232, 2012.

57. Norwood MG, Bailey N, Nanji M, Gillies RS, Nicholson A, Ubhi S, Darnton JJ, Steyn RS, Womack C, Hughes A, et al: Cytoplasmic beta-catenin accumulation is a good prognostic marker in upper and lower gastrointestinal adenocarcinomas. Histopathology 57: 101-111, 2010.

58. Kobayashi M, Honma T, Matsuda Y, Suzuki Y, Narisawa R, Ajioka $\mathrm{Y}$ and Asakura $\mathrm{H}$ : Nuclear translocation of beta-catenin in colorectal cancer. Br J Cancer 82: 1689-1693, 2000.

59. Guttridge DC, Albanese C, Reuther JY, Pestell RG and Baldwin AS Jr: NF-kappaB controls cell growth and differentiation through transcriptional regulation of cyclin D1. Mol Cell Biol 19: 5785-5799, 1999.

60. Yamamoto Y and Gaynor RB: Therapeutic potential of inhibition of the NF-kappaB pathway in the treatment of inflammation and cancer. J Clin Invest 107: 135-142, 2001.

61. Fryknas M, Dhar S, Oberg F, Rickardson L, Rydåker M, Göransson H, Gustafsson M, Pettersson U, Nygren P, Larsson R and Isaksson A: STAT1 signaling is associated with acquired crossresistance to doxorubicin and radiation in myeloma cell lines. Int J Cancer 120: 189-195, 2007. 
62. Roberts D, Schick J, Conway S, Biade S, Laub PB, Stevenson JP, Hamilton TC, O'Dwyer PJ and Johnson SW: Identification of genes associated with platinum drug sensitivity and resistance in human ovarian cancer cells. Br J Cancer 92: 1149-1158, 2005.

63. Hasegawa K, Ichikawa W, Fujita T, Ohno R, Okusa T, Yoshinaga K and Sugihara K: Expression of cyclooxygenase-2 (COX-2) mRNA in human colorectal adenomas. Eur J Cancer 37: 1469-1474, 2001.

64. Peek RM Jr: Prevention of colorectal cancer through the use of COX-2 selective inhibitors. Cancer Chemother Pharmacol 54 (Suppl 1): S50-S56, 2004.

65. Dempke W, Rie C, Grothey A and Schmoll HJ: Cyclooxygenase-2: A novel target for cancer chemotherapy? J Cancer Res Clin Oncol 127: 411-417, 2001.
66. Giercksky KE: COX-2 inhibition and prevention of cancer. Best Pract Res Clin Gastroenterol 15: 821-833, 2001.

67. Zhang H and Sun XF: Overexpression of cyclooxygenase-2 correlates with advanced stages of colorectal cancer. Am J Gastroenterol 97: 1037-1041, 2002.

(c) (i) (9) This work is licensed under a Creative Commons Attribution 4.0 International (CC BY-NC 4.0) License 